\title{
Mechanism of down regulation of luteinizing hormone receptors and steroidogenesis in corpora lutea
}

\author{
RAJAN R. DIGHE and N. R. MOUDGAL \\ Department of Biochemistry, Indian Institute of Science, Bangalore 560 012, India
}

MS received 7 November 1987; revised 11 May 1988

\begin{abstract}
The mechanism of 'down regulation' of luteinizing hormone receptors was investigated in pseudopregnant rats using a modified radioimmunoassay capable of measuring endogenous tissue-bound hormone. Treatment of pseudopregnant animals with a desensitizing dose (desensitization treatment) of human chorionic gonadotropin resulted in a decrease in receptor concentration. This decrease was prevented if the animals were treated prior to the desensitization treatment with indomethacin, an inhibitor of prostaglandin biosynthesis, suggesting a role for prostaglandins in down regulation. The desensitization treatment resulted in a time-dependent decrease in subsequent responsiveness of the tissue to luteinizing hormone. Basal progesterone production rate was also decreased following desensitization. Total tissue cholesterol was found to be decreased following desensitization treatment, without any change in the ratio of free to esterified cholesterol. Mitochondrial cholesterol was significantly reduced and pregnenolone production by the mitochondria of desensitized corpora lutea was also markedly reduced. However, when cholesterol was added to the mitochondria of desensitized corpora lutea, pregnenolone production was increased, reaching values almost equal to that shown by the control mitochondria. These results show that decrease in the responsiveness following desensitization treatment is due to, besides receptor loss, decrease in tissue cholesterol, in particular mitochondrial cholesterol. The cholesterol side chain cleavage activity, although low, appears to be functionally intact; the low activity could be attributed to low levels of mitochondrial cholesterol.
\end{abstract}

Keywords. Down regulation; desensitization; luteinizing hormone; steroidogenesis.

\section{Introduction}

It is a well-recognized property of several hormones and drugs that the primary stimulus modulates the responsiveness of the target tissue to subsequent exposure of the same tissue to the same hormone. This phenomenon is known as 'desensitization' or 'down regulation' and has been demonstrated for several hormones and growth factors. Administration of luteinizing hormone (LH) or human chorionic gonadotropin (hCG) has been shown to cause decrease in $\mathrm{LH}$ receptors both in ovaries and testes (Dufau and Catt, 1979). Such a decrease in receptors is also followed by decrease in responsiveness of the tissue to the same stimulus (Dufau and Catt, 1979). It was further demonstrated that steroidogenesis in desensitized tissue could not be stimulated by dibutyryl cAMP or cholera toxin, suggesting a defective steroidogenic pathway (Conti et al., 1977). However, the mechanism by which the hormones cause decrease in the receptors and alter the responsiveness of the tissue is poorly understood. In the present study an attempt has been made to unravel the mechanism by which $\mathrm{LH}$ receptor loss and decrease in responsiveness occur using corpora lutea from pseudopregnant rats as the model system.

Abbreviations used: LH, Luteinizing hormone; hCG, human chorionic gonadotropin; oLH, ovine LH; PMSG, pregnant mare serum gonadotropin; RIA, radioimmunoassay; SSC, side chain cleavage. 


\section{Materials and methods}

\section{Hormones and chemicals}

hCG used in this study was a kind gift of Dr C. R. Canfield, USA. Ovine LH (oLH) was a gift of Dr M. R. Sairam, Canada. Pregnant mare serum gonadotropin (PMSG) was purchased from Sigma Chemical Co., St. Louis, Missouri, USA. [ $\left.{ }^{3} \mathrm{H}\right]$ Progesterone, $\left[{ }^{3} \mathrm{H}\right]$ pregnenolone and $\mathrm{Na}^{125}$ I were purchased from the Radiochemical Centre, Amersham, UK. All reagents used in this study were of analytical grade.

\section{Animals}

Immature female rats 25-26 days of age were rendered pseudopregnant by injecting subcutaneously $15 \mathrm{IU}$ of PMSG followed $56 \mathrm{~h}$ later by $50 \mathrm{IU}$ of hCG. Four to five days after hCG treatment the animals were treated with either saline or a desensitizing dose of hCG (referred to hereafter as 'desensitization treatment') and killed after various times depending on the experimental design. Ovaries were removed, and corpora lutea were dissected free of adhering fat using a fine needle and processed according to different experimental designs.

\section{Radioimmunoassay of tissue-bound $h C G$}

Luteal tissue-bound hCG was determined essentially according to the procedure previously used for tissue-bound LH (Muralidhar and Moudgal, 1976a, b) and tissuebound follicle stimulating hormone (Sheela Rani and Moudgal, 1978). Corpora lutea

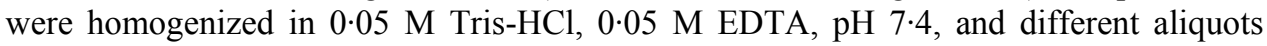
were used for assaying hCG in the tissue by radioimmunoassay (RIA) carried out at $37^{\circ} \mathrm{C}$ as described by Muralidhar and Moudgal (1976a, b).

\section{Determination of responsiveness of corpora lutea}

Responsiveness of the corpora lutea from control and hCG-treated animals to LH was determined by incubating the corpora lutea in Krebs-Ringer bicarbonate medium, $\mathrm{pH} 7 \cdot 4$, containing $0.05 \mathrm{M}$ Hepes and $0.1 \%$ bovine serum albumin (BSA) in the absence or presence of $\mathrm{LH}(0 \cdot 1,1$ and $10 \mu \mathrm{g} / \mathrm{ml} \mathrm{oLH})$ for $2 \mathrm{~h}$ at $37^{\circ} \mathrm{C}$. Progesterone secreted into the medium was estimated by a specific RIA.

\section{Determination of luteal tissue cholesterol}

Corpora lutea were obtained from animals killed 12 or $24 \mathrm{~h}$ after desensitization treatment. The corpora lutea from individual animals were suspended in saline and stored frozen until further use. To determine luteal tissue cholesterol and esterified cholesterol, corpora lutea were homogenized in $0.15 \mathrm{M} \mathrm{NaCl}$ and total lipids were extracted using a chloroform: methanol mixture (final composition, chloroform: methanol: saline 1:1:0.9). Cholesterol and esterified cholesterol were separated by thin-layer chromatography using hexane: ether: acetic acid (30:10:0.5) as the solvent system and estimated by the method of Glick et al. (1964). 


\section{Determination of cholesterol side chain cleavage activity}

Cholesterol side chain cleavage (SSC) activity of the mitochondria-rich preparation was assayed by estimating pregnenolone produced by the mitochondria. Corpora lutea were homogenized in $0.05 \mathrm{M}$ Tris- $\mathrm{HCl}, \mathrm{pH} 7 \cdot 4$, containing $0.5 \mathrm{mM}$ EDTA and $0 \cdot 25 \mathrm{M}$ sucrose. The homogenate was spun at $600 \mathrm{~g}$ for $10 \mathrm{~min}$. The supernatant was retrieved and centrifuged at $8500 \mathrm{~g}$ for $15 \mathrm{~min}$. The pellet was resuspended in the same buffer after washing and used for determining SSC activity. Aliquots of mitochondria (approximately $300 \mu \mathrm{g}$ protein) were incubated in a total volume of $1 \mathrm{ml}$ of a solution containing $5 \mathrm{mM} \mathrm{Ca}{ }^{2+}, 5 \mathrm{mM} \mathrm{Mg}^{2+}, 40 \mathrm{mM}$ nicotinamide, and $10 \mathrm{mM}$ sodium succinate. Cholesterol $(100 \mu \mathrm{M})$, whenever present, was added in $50 \mu \mathrm{l}$ absolute ethanol; all other aliquots received the same volume of ethanol. The reaction was initiated by adding the mitochondrial preparation and was continued for $30 \mathrm{~min}$ at $37^{\circ} \mathrm{C}$. The reaction was terminated by placing the tubes in a boiling water bath for $1 \mathrm{~min}$. Steroids formed were extracted with ether, and separated by thin-layer chromatography using chloroform: ethyl acetate (4:1) as the solvent system. Using this system, it was possible to separate pregnenolone from progesterone. Pregnenolone was then estimated by RIA using $7-\left[{ }^{3} \mathrm{H}\right]-$ pregnenolone as the tracer and a progesterone antiserum with $100 \%$ cross-reactivity with pregnenolone.

\section{Results}

\section{Demonstration of down regulation of $L H$ receptors}

Pseudopregnant rats were treated subcutaneously with saline or a desensitizing dose of hCG $(4 \mu \mathrm{g})$. The animals were again treated after $48 \mathrm{~h}$ with hCG (2 or $4 \mu \mathrm{g})$ and killed $3 \mathrm{~h}$ later. Tissue-bound hCG was determined by RIA. It was earlier found that maximum uptake of hCG by the ovaries occurs $3 \mathrm{~h}$ after a subcutaneous injection of hCG and the uptake was maximal when $4 \mu \mathrm{g}$ of hCG were administered, suggesting saturation of LH receptors in vivo. As shown in table 1, animals that had received desensitization treatment showed a significant decrease in uptake of hCG, demonstrating down regulation of LH receptors following desensitization treatment.

\section{Involvement of prostaglandins in down regulation of LH receptors}

The involvement of prostaglandins in the process of down regulation of $\mathrm{LH}$

Table 1. Down regulation of $\mathrm{LH}$ receptors.

\begin{tabular}{|c|c|c|c|}
\hline \multirow[b]{2}{*}{ Group } & \multicolumn{2}{|c|}{ hCG $(\mu \mathrm{g})$ treatment at } & \multirow{2}{*}{$\begin{array}{l}\text { Luteal tissue } \mathrm{hCG} \\
\text { (ng/10 mg tissue)* }\end{array}$} \\
\hline & $\mathrm{Ob}$ & $48 \mathrm{~h}$ & \\
\hline A & - & 一 & $0.05 \pm 0.11$ \\
\hline B & - & 2 & $1290 \pm 29$ \\
\hline $\mathrm{C}$ & 一 & 4 & $19 \cdot 40 \pm 2 \cdot 4$ \\
\hline D & 4 & - & $0.19 \pm 0.03$ \\
\hline $\mathrm{E}$ & 4 & 2 & $2 \cdot 74 \pm 1.17$ \\
\hline $\mathbf{F}$ & 4 & 4 & $2 \cdot 47 \pm 0.65$ \\
\hline
\end{tabular}

*Values are mean $\pm \mathrm{SD}, \mathrm{n}=4$.

Group E significantly different from Group B, $P<0 \cdot 001$.

Group F significantly different from Group C, $P<0.001$. 
receptors was investigated by studying the effect of a prostaglandin synthesis inhibitor on hCG-induced receptor loss. The animals were administered 1 and $4 \mu \mathrm{g}$ of hCG as a desensitization treatment and uptake of hCG $3 \mathrm{~h}$ following the administration of $5 \mu \mathrm{g}$ of $\mathrm{hCG} 48 \mathrm{~h}$ after desensitization was determined. One group of animals was treated with $500 \mu \mathrm{g}$ indomethacin $1 \mathrm{~h}$ prior to desensitization treatment and hCG uptake by luteal tissue was determined as described above. As shown in table 2 , the desensitizaton treatment resulted in a dose-dependent decrease in hCG

Table 2. Effect of indomethacin on hCG-induced receptor loss.

\begin{tabular}{|c|c|c|c|c|}
\hline & & tment & & Luteal tissue hCG \\
\hline & $-1 h$ & $0 \mathrm{~h}$ & $48 \mathrm{~h}$ & (ng/10 mg tissue)* \\
\hline Group & $\begin{array}{l}\text { Indometha- } \\
\operatorname{cin}(\mu \mathrm{g})\end{array}$ & $\begin{array}{r}h C G \\
(\mu \mathrm{g})\end{array}$ & $\begin{array}{r}\mathrm{hCG} \\
(\mu \mathrm{g})\end{array}$ & \\
\hline A & - & - & 5 & $9.5 \pm 1.5$ \\
\hline B & 一 & 4 & - & $0.45 \pm 0.05$ \\
\hline $\mathrm{C}$ & - & 4 & 5 & $2 \cdot 15 \pm 0 \cdot 18$ \\
\hline$D$ & 500 & 4 & 一 & $0.38 \pm 0.05$ \\
\hline $\mathrm{E}$ & 500 & 4 & 5 & $2.9 \pm 0.13$ \\
\hline $\mathrm{F}$ & - & 1 & - & ND \\
\hline $\mathrm{G}$ & - & 1 & 5 & $3.5 \pm 0.3$ \\
\hline $\mathrm{H}$ & 500 & 1 & 5 & $8.6 \pm 1.45$ \\
\hline
\end{tabular}

uptake by the corpora lutea, suggesting loss of LH receptors. Indomethacin treatment reduced receptor loss. This effect was only marginal when the desensitizing dose was $4 \mu \mathrm{g}$ but completely prevented receptor loss when the desensitizing dose was $1 \mu \mathrm{g}$.

\section{Effect of desensitization treatment on responsiveness of the corpora lutea}

Corpora lutea obtained from rats after various times following desensitization treatment were incubated with different concentrations of oLH or without oLH for $2 \mathrm{~h}$ at $37^{\circ} \mathrm{C}$. Progesterone secreted into the medium was estimated by RIA. As shown in figure 1 , the control corpora lutea $(0 \mathrm{~h})$ responded to $\mathrm{LH}$ in vitro by producing increased progesterone. However, the corpora lutea obtained 4, 12, 24 and $48 \mathrm{~h}$ after the desensitizing dose did not show any responsiveness to $\mathrm{LH}$ added in vitro. The corpora lutea obtained $4 \mathrm{~h}$ after desensitizing treatment showed increased basal production in vitro but did not show any further responsiveness. Corpora lutea obtained 12, 24 and even $48 \mathrm{~h}$ after the desensitization treatment showed decreased basal production of progesterone.

\section{Effect of desensitization treatment on sterol levels of luteal tissue}

Endogenous cholesterol and esterified cholesterol levels were determined in luteal tissue 12 and $24 \mathrm{~h}$ following desensitization treatment. Untreated animals served as 


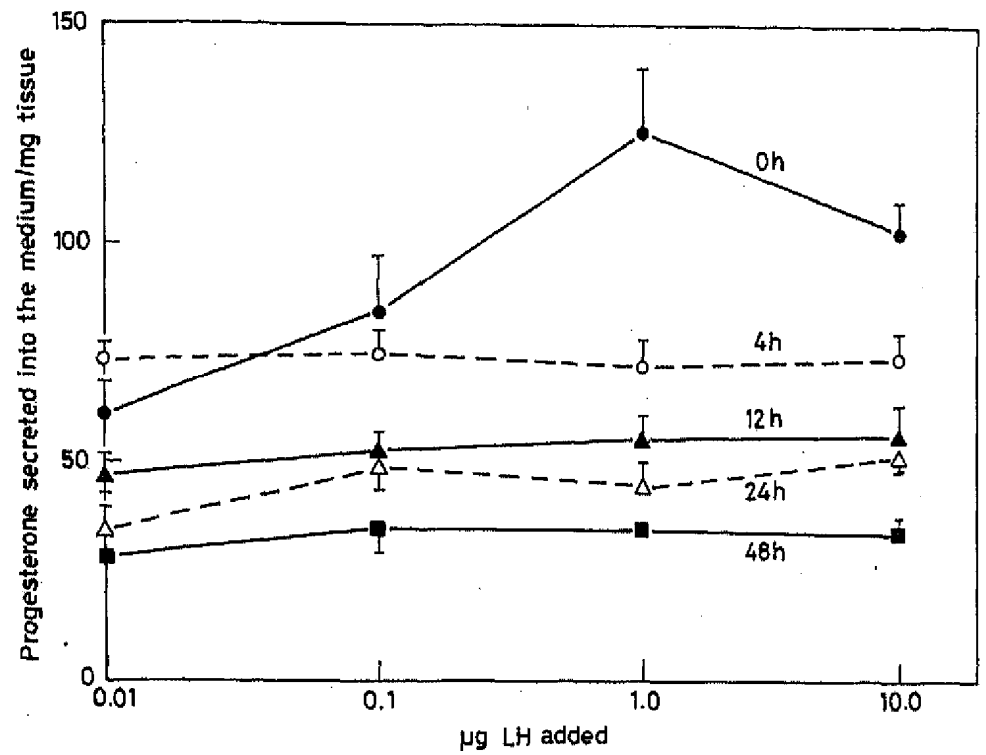

Figure 1. In vitro responsiveness of the corpora lutea following a desensitization treatment. Corpora lutea were obtained from animals 4, 12, 24 and $48 \mathrm{~h}$ after treatment; $0 \mathrm{~h}$ indicates untreated animals (control). Each point is the mean $\pm \mathrm{SD}$ of triplicates.

controls. As shown in table 3 there was a significant decrease in cholesterol levels $(P<0 \cdot 05)$, although by $24 \mathrm{~h}$ the cholesterol levels appear to be higher than at $12 \mathrm{~h}$

Table 3. Endogenous free and esterified cholesterol in control and desensitized corpora lutea.

\begin{tabular}{lccc}
\hline $\begin{array}{l}\text { Time after hCG } \\
\text { treatment } \\
(\mathrm{h})\end{array}$ & $\begin{array}{c}\text { Cholesterol } \\
(\mu \mathrm{g} / \mathrm{mg} \text { tissue })\end{array}$ & $\begin{array}{c}\text { Esterified cholesterol as } \\
\text { cholesterol equivalent } \\
(\mu \mathrm{g} / \mathrm{mg} \text { tissue })\end{array}$ & $\begin{array}{c}\text { Total } \\
\text { cholesterol* } \\
(\mu \mathrm{g} / \mathrm{mg} \text { tissue })\end{array}$ \\
\hline 0 & $0.99 \pm 0.13$ & $2 \cdot 36 \pm 0.24$ & $3.37 \pm 0.37$ \\
12 & $0.63 \pm 0.12$ & $1.54 \pm 0.36$ & $2.46 \pm 0.40$ \\
24 & $0.73 \pm 0.14$ & $1.88 \pm 0.29$ & $2.61 \pm 0.40$ \\
\hline
\end{tabular}

*Values are mean $\pm \mathrm{SD}, \mathrm{n}=4$.

Significance of difference: Cholesterol $12 \mathrm{~h} v s 0 \mathrm{~h}, P<0.05$; cholesterol $24 \mathrm{~h} v s 0 \mathrm{~h}$, not significant; cholesterol ester, $12 \mathrm{~h} v s 0 \mathrm{~h}, P<0.05$; cholesterol ester $24 \mathrm{~h} v s 0 \mathrm{~h}$, not significant; total cholesterol $12 \mathrm{~h} v s 0 \mathrm{~h}, P \simeq 0.05$.

and not significantly different from $0 \mathrm{~h}$ levels. A similar pattern was observed for esterified cholesterol, and for free and esterified cholesterol taken together (total cholesterol). However, total cholesterol present in the mitochondria obtained from pooled corpora lutea was markedly reduced even $24 \mathrm{~h}$ after the desensitization treatment (table 4).

\section{Effect of desensitization treatment on cholesterol side chain cleavage activity}

Mitochondria prepared from corpora lutea obtained from control and hCGdesensitized animals were used for determining cholesterol side chain cleavage 
Table 4. Cholesterol levels in mitochondria-rich preparation obtained from control and desensitized corpora lutea.

\begin{tabular}{lc}
\hline Treatment & $\begin{array}{c}\text { Mitochondrial cholesterol } \\
(\mu \mathrm{g} / \mathrm{mg} \text { protein })\end{array}$ \\
\hline Saline & 27.6 \\
hCG $(4 \mu \mathrm{g})$ & 13.95 \\
\hline
\end{tabular}

Animals were killed $24 \mathrm{~h}$ after treatment.

activity. As shown in table 5, pregnenolone production by mitochondria from hCGtreated rats was significantly lower than that by control mitochondria. While addition of exogenous cholesterol to mitochondria from control corpora lutea did

Table 5. Cholesterol side chain cleavage activity in control and desensitized luteal mitochondria.

\begin{tabular}{lc}
\hline Group & $\begin{array}{c}\text { Pregnenolone formed } \\
\text { (pmol/mg protein)* }\end{array}$ \\
\hline $\begin{array}{l}\text { A Control luteal mitochondria } \\
\text { B Desensitized luteal mitochon- } \\
\text { dria }\end{array}$ & $205 \cdot 9 \pm 37 \cdot 4$ \\
$\begin{array}{l}\text { C Control luteal mitochondria } \\
\quad+\text { cholesterol }\end{array}$ & $180 \cdot 1 \pm 40 \cdot 0$ \\
$\begin{array}{l}\text { D Desensitized luteal mitochon- } \\
\text { dria + cholesterol }\end{array}$ & $200 \cdot 1 \pm 51 \cdot 6$ \\
\hline
\end{tabular}

Animals were killed $24 \mathrm{~h}$ after desensitization treatment or saline injection (control).

*Values are mean $\pm \mathrm{SD}, \mathrm{n}=4$.

Significance of difference: B vs A, $P<0.001$; D vs B, $P<0.025$;

C vs D, not significant.

not enhance pregnenolone formation, the mitochondria from desensitized luteal tissue showed stimulated production of pregnenolone and this was equal to that produced by the control mitochondria.

\section{Discussion}

In the studies presented above an attempt has been made to understand the mechanism of down regulation of $\mathrm{LH}$ receptors and the subsequent reduction in responsiveness of the corpora lutea. The down regulation of receptors was demonstrated using an RIA system extensively validated earlier (Muralidhar and Moudgal, 1976a, b; Sheela Rani and Moudgal, 1978; Dighe, 1982) for measurement of physiologically active LH bound to receptors. With this assay system it has been demonstrated here that decrease in hormone uptake following desensitization treatment was indeed due to a true loss of the receptors and not due to decrease in binding of the hormone to the receptors caused by higher occupancy of the receptors after the desensitization treatment. 
Prostaglandins have been implicated in bringing about luteolysis in several species Labhsetwar, 1975; Zor and Lamprecht, 1977; Behrman, 1979). Prostaglandins have also been shown to cause reduction in LH receptor concentration (Hichens et al., 1974; Grinwich et al., 1976a, b; Behrman and Hichens, 1976; Behrman et al., 1978). In the present study it has been shown that inhibition of prostaglandin biosynthesis by indomethacin treatment prevented hCG-induced receptor loss. The protection provided by indomethacin was dependent on the dose of indomethacin, $500 \mu \mathrm{g}$ being the most effective dose (data not shown). At this dose inhibition of receptor loss was partial if the desensitizing dose of $\mathrm{hCG}$ was $4 \mu \mathrm{g}$ but complete inhibition of receptor loss was observed when the desensitization dose of hCG was reduced to $1 \mu \mathrm{g}$. These results provide confirmatory evidence for the involvement of prostaglandins in regulating luteal cell $\mathrm{LH}$ receptor concentration. One of the events that occur following binding of the hormone to the receptor is perhaps stimulation of prostaglandin biosynthesis which in turn initiates down regulation of receptor. Haour et al. $(1979 \mathrm{a}, \mathrm{b})$ have noted that in the Leydig cell prostaglandin levels increase $6 \mathrm{~h}$ following hCG administration. In the present study it was also found that administration of indomethacin $90 \mathrm{~min}$ or $6 \mathrm{~h}$ after desensitization treatment did not prevent the receptor loss (data not shown). Thus receptor loss, once initiated, could not be prevented by indomethacin administration.

A decrease in the receptor concentration was also accompanied by decrease in responsiveness of the corpora lutea. Progesterone production decreased in a timedependent fashion and was reflected both in basal rate of progesterone production as well as in response to LH in vitro. This suggested that in addition to receptor loss significant alterations in the progesterone biosynthetic pathway should be occurring. There is a large body of evidence to show that loss of $\mathrm{LH}$ receptors is also accompanied by several lesions in the steroid biosynthetic pathway. Luteal adenylyl cyclase activity was found to be decreased following administration of a desensitizing dose of hCG to pseudopregnant rabbits (Hunzicker-Dunn and Birnbaumer, 1976). Further, it was shown that desensitized Leydig cells responded to cholera toxin with increased cAMP production, but failed to respond in terms of testosterone production (Tsuruhara et al., 1977). It has also been observed that desensitized luteal cells do not respond to cholera toxin and dibutyryl cAMP in terms of progesterone production (Conti et al., 1977). In the case of Leydig cells the lesion in testosterone biosynthesis was identified as a decrease in the activities of the enzymes 17-20 lyase (Cigorraga et al., 1978) and $17 \alpha$ hydroxylase (Chaslow et al., 1979). However, such defects have not been identified in luteal cells. The levels of cholesterol and esterified cholesterol were found to be decreased in corpora lutea obtained from hCG-treated animals. However it must be noted that there was no decrease in the ratio of free to esterified cholesterol. Down regulation, as described here, results in decrease in progesterone biosynthesis and this is similar to that occurring in corpora lutea undergoing functional luteolysis. Blockade or reduction in endogenous LH availability brought about by LH antibody treatment resulted in significant accumulation of esterified cholesterol in the luteal tissue (Moudgal et al., 1972; Behrman et al., 1972; Mukku and Moudgal, 1980) and this was unlike that observed in desensitized corpora lutea. Corpora lutea undergoing luteolysis remained responsive to added LH in vitro in terms of progesterone production, though this declined with time (Mukku and Moudgal, 1980); however, the desensitized corpora lutea did not respond to $\mathrm{LH}$ at all. These results suggest that there is a fundamental 
difference between luteolysis brought about by LH removal and desensitization brought about by LH receptor down regulation.

The desensitized corpora lutea also showed marked decrease in mitochondrial cholesterol. Only part of the mitochondrial cholesterol is available to the side chain cleavage activity (see Dorrington, 1977). Hence the effect of a decrease in the cholesterol level of mitochondria on side chain cleavage activity is probably enhanced further. There was a significant decrease in pregnenolone production by mitochondria from desensitized corpora lutea. This defect in pregnenolone biosynthesis could be ameliorated by addition of cholesterol to the mitochondrial preparation: pregnenolone production by mitochondria from desensitized corpora lutea in the presence of exogenous cholesterol was nearly equal to that by control mitochondria. These results suggest that the cholesterol side chain cleavage activity is probably functionally intact, and the decrease in progesterone biosynthesis could be due to the decrease in the cholesterol pool in mitochondria which acts as the substrate for cholesterol side chain cleavage enzymes. Replenishment of the mitochondrial cholesterol pool may take a much longer time than that of tissue cholesterol. Levels of tissue cholesterol had returned to nearly control levels $24 \mathrm{~h}$ following desensitization treatment, but cholesterol in the mitochondria remained markedly reduced. There was no change in $3 \beta$-hydroxy-steroid dehydrogenase in desensitized corpora lutea but a significant increase in cAMP phosphodiesterase activity was noted (data not shown). This defect can cause further decrease in progresterone biosynthesis.

Thus down regulation of luteal tissue following administration of hCG occurs at at least two different levels-(i) loss of receptors which is perhaps mediated by prostaglandins and (ii) decrease in the cholesterol pool resulting in decrease in progesterone production.

\section{Acknowledgements}

Financial aid by the Indian Council of Medical Research, New Delhi and the Small Supplies Programme of the World Health Organization is gratefully acknowledged. The authors are also grateful to Dr M. R. Sairam and Dr C. R. Canfield for supply of hormones.

\section{References}

Behrman, H. R. (1979) Annu. Rev. Physiol., 41, 685.

Behrman, H. R., Grinwich, D. L., Hichens, M. and Macdonald, G. J. (1978) Endocrinology, 103, 349.

Behrman, H. R. and Hichens, M. (1976) Prostaglandins, 12, 83.

Behrman, H. R., Moudgal, N. R. and Greep, R. O. (1972) J. Endocrinol.; 52, 419.

Chaslow, F., Mar, H., Haour, F. and Saez, M. (1979) J. Biol Chem., 254, 5615.

Cigorraga, S. D., Dufau, M. L. and Catt, K. J. (1978) J. Biol Chem., 253, 4297.

Conti, M., Harwood, J. P., Hsueh, A. J. W., Dufau, M. L. and Catt, K. J. (1977) J. Biol. Chem., 251, 7729.

Dighe, R. R. (1982) Studies on gonadotropin-Studies on LH-hCG receptor interaction and regulation of $\mathrm{LH}$ receptors and steroidogenesis, Ph.D. Thesis, Indian Institute of Science, Bangalore.

Dorrington, J. H. (1977) Ovary, 3, 359.

Dufau, M. L. and Catt, K. J. (1979) Vitam. Horm., 36, 461.

Glick, D., Fell, B. F. and Sjolin, K. E. (1964) Anat. Chem., 36, 1119.

Grinwich, D. L., Ham, E. A., Hichens, M. and Behrman, H. R. (1976a) Endocrinology, 98, 146.

Grinwich, D. L., Hichens, M. and Behrman, H. R. (1976b) Biol. Reprod., 14, 212. 
Haour, F., Kouznetzova, B., Dray, F. and Saez, M. (1979a) Life Sci., 24, 2151.

Haour, F., Kouznetzova, B. and Dray, F. (1979b) Proceedings of the 61st Meeting of the Endocrine Society, Anaheim, USA, Abs. No. 508.

Hichens, M., Grinwich, D. L. and Behrman, H. R. (1974) Prostaglandins, 7, 449.

Hunzicker-Dunn, M. and Birnbaumer, L. (1976) Endocrinology, 99, 211.

Labhsetwar, A. P. (1975) in Prostaglandins and reproduction (ed. S. M. M. Karim) (Edinburgh: M.T.P. Press Ltd.) p. 241.

Moudgal, N. R., Behrman, H. R. and Greep, R. O. (1972) J. Endocrinol., 52, 413.

Mukku, V. R. and Moudgal, N. R. (1980). J. Biosci., 1, 457.

Muralidhar, K. and Moudgal, N. R. (1976a) Biochem. J., 160, 603.

Muralidhar, K. and Moudgal, N. R. (1976b) Biochem. J., 160, 607.

Sheela Rani, C. S. and Moudgal, N. R. (1978) Mol. Cell Endocrinol., 11, 293.

Tsuruhara, T., Dufau, M. L., Cigorraga, S. and Catt, K. J. (1977) J. Biol. Chem., 252, 9002.

Zor, U. and Lamprecht, S. A. (1977) Biochem. Actions Horm., 4, 85. 